\title{
Grundtvig-samlingen på Instituttet for Dansk Kirkehistorie.
}

Af Knud Eyvin Bugge.

For ca. halvandet år siden udsendte Instituttets forstander, prof. Hal Koch to artikler, dels i Dansk Teologisk Tidsskrift ( I956, s. I93 ff), dels i Præsteforeningens Blad ( 1957, s. 38 ff), hvori han gjorde rede for Instituttets oprettelse, arbejde og formål. I den første af disse artikler blev det omtalt, at Instituttet ejede en Grundtvig-Samling, som der næppe fandtes mage til noget sted her i landet. Denne udtalelse vakte stor interesse $i$ vide kredse, også langt ud over Grundtvigforskernes snævre kreds, ja den blev endog genstand for omtale i dagspressen. Disse linier er da skrevet for at imødekomme denne interesse med en redegørelse, hvorfor denne samling må anses for at være en af de mest fuldstændige, der findes. Om det er den fineste Gr.samling, der eksisterer, må i nogen grad bero på et skøn. Sikkert er det i hvert tilfælde, at Instituttets Gr.samling rummer en række Grundtvigiana, der ikke findes andre steder.

Først lidt om samlingens proveniens. Hovedstammen udgøres af den såkaldte »Thorsenske Samling «, der i foråret 1947 blev købt til Theologisk Laboratorium med det kommende Institut for Dansk Kirkehistorie for øje. I de sidste ı o-I I år har samlingen da været opbevaret $\mathrm{i}$ et skab på Theologisk Laboratoriums assistentværelse. Men nu er tidspunktet kommet, hvor det skal afsløres, hvad denne samling indeholder for kostbarheder.

Inspektør Nicolai Frederik Thorsen blev født i i 866 og døde som 8o-årig i i 946. Han voksede op i et af Gr. påvirket lærerhjem på Mors, ja den grundtvigske påvirkning var så stærk, at barnet i Dåben blev opkaldt efter Gr. Han var uddannet på Hærens Elevskole, men gik i begyndelsen af halvfemserne over i Københavns Kommunes tjeneste og endte sine dage som inspektør ved Vejvæsenets oplagspladser. Thorsens bibliotek omfattede ved hans død over i 5.000 bind. Foruden Gr.samlingen ejede han en af landets fineste topografiske samlinger samt en betydelig skønlitterær samling indeholdende vær- 
ker væsentlig fra Guldalderen. Det maskinskrevne katalog over den Thorsenske Gr. samling omfatter ca. 850 numre, selv når tidsskrifter og værker i flere bind regnes som eet nummer. Når samlingen er blevet så stor, skyldes det bl. a. dette, at Thorsen ikke lod sig nøje med eet eksemplar af et Gr.skrift, hvis dette fandtes trykt på forskellige slags papir. For at tage et par eksempler vilkårligt valgt blandt Gr.s ældste skrifter, så findes i samlingen eksemplarer både på trykpapir og på skrivepapir af såvel »Indbydelse til Gamle Nordens Venner« som af »Maskeradeballet i Dannemark «, begge fra 1808. - Endv. har Thorsen lagt vægt på altid at bevare de originale omslag. »Den rigtige Grundtvigsamler stræber naturligvis helst efter at erhverve sig originaludgaverne i de oprindelige omslag...«, siger Steen Johansen $\mathrm{i}$ indledningen til tredie bind af Bibliografien. Og Thorsen var netop en sådan »rigtig Grundtvigsamler«. Under den mere detaillerede gennemgang af samlingen vil vi stifte bekendtskab med de mest interessante af disse omslag og med de spørgsmål, som de frembyder. Kunde Thorsen få fat på et ubeskåret eksemplar af et skrift, så har han ikke skyet nogen anstrengelse for at få det med. Og det gælder både større værker som f. eks. »Kort Begreb af Verdens Krønike, betragtet i Sammenhæng《, I8I4, »Roskilde-Riim《 og »RoskildeSaga«, ligeledes fra I8 I4, eller mindre skrifter som f. eks. prædikenen »Hvad skal vi giøre, at vi kan arve det evige Liv? « fra 18 i 3 eller »Fædrene-Aaret《 fra I 8 I 5 o.fl. Et morsomt, næsten kvadratisk, ubeskåret eksemplar af Gr.s »Den danske Stats-Kirke upartisk betragtet « fra I834 skal nævnes som eksempel på et ubeskåret skrift fra de senere år.

Men skrifter kan jo også have interesse i kraft af det, som folk har indskrevet i dem, her tænkes på sådan noget som dedikationer, ejernavne, marginaltilføjelser $\mathrm{m}$. $\mathrm{m}$. Den Thorsenske samling indeholder således en hel del bøger, der har tilhørt Gr.s allernærmeste familie, f. eks. Svend Gr., F. L. Gr., Fru Asta Gr., Laura Gr. og Jane Blicher. Men også bøger, der har tilhørt Gr.s nærmeste vennekreds, har interesseret samleren Thorsen; det gælder f. eks. bøger, der har tilhørt Chr. Molbech, eller Ingemann, Chr. Ley, D. P. Smith eller Jonna Stampe. Af bøger, der har tilhørt discipelkredsen i videste forstand, eller har tilhørt kendte mænd i Gr.s samtid, kan nævnes bøger, der har tilhørt D. G. Monrad, Skat Rørdam, Martensen og V. J. Hoff. Ordlyden af de egenhændige dedikationer, som Gr. har indskrevet i adskillige af disse bøger, vil vi senere vende tilbage til. Enkelte korrektureksemplarer haves også i samlingen. Værdien af sådanne korrektur- 
eksemplarer kan ikke sættes højt nok. Her får vi et indblik i selve forfatterens værksted! Eksemplarer af bøger med Gr.s egenhændige tilføjelser, kommentarer o. 1 . vender vi tilbage til under omtalen af den lille samling af bøger, der vides at have tilhørt Gr. selv.

Foruden egentlige bøger og pjecer rummer den Thorsenske samling en række udsnit af samtidige dagblade og tidsskrifter, og det gælder såvel tryk af Gr. som tryk til og om Gr. Således er vi i stand til at følge Gr.s opgør med Molbech i årene omkring r 8 I o gennem disse udsnit, ligesom vi også kan følge diskussionen med R. K. Rask først på året I 8 I 0 ang. oversættelsen af Edda. - Som den ordensmand Thorsen var, har han omhyggeligt indbundet alle disse udsnit i små, sirlige bind. I det hele taget er samlingen særdeles velkonserveret. Mange af indbindingerne er rene kunstværker. Det har heller ikke været billigt for Thorsen at samle alle disse Grundtvigiana. Det kan man bl. a. se deraf, at han til tider har noteret prisen på indersiden af omslagene. F. eks. fremgår det således, at han har betalt 35.- kr. for Gr.s »En ganske ny Vise om den mandhaftige Jydske Ridder Herr Niels Ebbesen til Nørreriis, « r 839, et tryk på 4 sider i oktavformat! Til denne samling af skrifter af og om Gr. slutter sig en større samling af skrifter, der belyser Grundtvigianismens historie, samt en række skrifter af og om Gr.s slægtninge. Endelig må nævnes en samling med noder til Gr.s salmer og digte. Vi skulde da - foreløbigt - være færdig med omtalen af den Thorsenske samling.

$\mathrm{Nu}$ ang. den senere supplering af Instituttets Gr. samling: I foråret $195^{\circ}$ købtes til Theologisk Laboratorium, som et supplement til den Thorsenske samling, en billedsamling omfattende 83 billeder plus en samling på ca. I 7o udklip af aviser og tidsskrifter, hvoraf de fleste er forsynet med omslag og titel. Denne samling var blevet skabt af nu afdøde grosserer H. I. Andersen, ved hans død købt af Rosenkilde og Bagger og da - i forået I950 - købt af Theologisk Laboratorium. Senere er Instituttets Gr.samling blevet suppleret med en del Gr. litteratur fra Theologisk Laboratoriums afdeling for dansk kirkehistorie, som blev overført til Instituttet ved dettes oprettelse i efteråret I956. Siden den tid er Gr. litteraturen - og da også i enkelte tilfælde samlingen af Gr. tekster - blevet suppleret dels ved gaver, dels ved køb.

Vi kan nu vende os til en mere detailleret gennemgang af samlingen. Det vil imidlertid være umuligt at dvæle ved hver enkelt publikation, ej heller er det muligt at gøre opmærksom på de forskellige 
»huller« i samlingen. Det bliver nødvendigt at gennemgå samlingen på den måde, at man kun slår ned på de mest bemærkelsesværdige udgivelser. - Blandt de tidligste bemærkes et udsnit af Ny Minerva 1806 med Gr.s afhandling »Lidet om Sangene i Edda.« Denne afhandling er, som bekendt, det første, Gr. lod trykke efter sin ankomst til Langeland. Går vi lidt længere frem i bogrækken, finder vi Molbechs eksemplar af »Nordens Mytologi«, I808. I eksemplaret har Molbech indskrevet sit navn og årstallet $\mathrm{I} 808$. - Fra kriseåret $\mathrm{I} 8 \mathrm{I}$ I $\mathrm{er}$ der tre småskrifter, der påkalder vor interesse. Det gælder for det første Gr.s berømte dimisprædiken med det originale, bløde omslag. Dernæst kommer vi til Gr.s »Sørgekvad ved Prinds Kristians Død «. Eksemplaret er prydet med et portræt af prins Kristian, og det bemærkes, at et sådant eksemplar med portræt ikke kendes andet sted fra. Fra december I8 10 haves bl. a. to eksemplarer af Gr.s »Nytaarsnat《. Det ene er $i$ et samtidigt papbind, det andet $i$ en senere indbinding. Dette sidstnævnte er interessant derved, at det har tilhørt den senere biskop og politiker D. G. Monrad. Han har skrevet sit navn på bogens titelblad og har tilføjet: »den I4. September 1826. Dux i November.« Bogen er derfor sandsynligvis blevet Monrads ejendom, mens han endnu var elev i Vordingborg Latinskole. Går vi videre i rækken, ser vi Gr.s »Optrin af Nordens Kæmpeliv I-II«, I 8og-I I i smukke, samtidige læderbind. Eksemplaret har tilhørt Gr.s ven, den senere provst Daniel Peter Smith.

De næste udgivelser, der skal omtales, er dels $\gg$ Kort Begreb af Verdens Krønike i Sammenhæng«, I812, og »Bjowulfs Drape«, 1820. Begge disse publikationer er interessante derved, at de er dedikationseksemplarer. I førstnævnte har Gr. skrevet »Til Historiens christelige Gransker Prof. Vedel Simonsen venskabelig fra Forfatteren«. I sidstnævnte, Bjowulfs Drape, har han indskrevet et dedikationsdigt til baronesse Jonna Stampe. Digtet er senere trykt i Svend Gr.s udgave af Gr.s Poetiske Skrifter, Bd. VII, hvor Svend Gr. skriver over digtet: »Hidtil utrykt. I et Exemplar af Bjovulfs Drape.« Dette af Svend Gr. omtalte eksemplar af Bjowulfs Drape findes altså i Instituttets Gr. samling.

Vi gør nu et spring fremad til udgaven af et af Gr.s allerbedst kendte digte, $\gg$ Nyaars-Morgen fra I 824. Dette eksemplar er bemærkelsesværdigt i mere end een henseende. For det første bærer det udvendig på omslaget påskriften »Donum autoris«, d.v.s. gave fra forfatteren. På indersiden af omslaget er skrevet - men ikke med Gr.s 
håndskrift - »En Foræring af Forfatteren til K. E. Møhl.« Møhl er sandsynligvis den fhv. missionær, pastor Knud Eskild Møhl i Ølstykke $\left.^{1}\right)$. Men det mest bemærkelsesværdige ved den nærværende udgave af Gr.s berømte digt er dets originale, gule omslag med trykket »Nyaars-Morgen« indf. en rectangulær forsiring. Da første bind af Bibl. ${ }^{2}$ ) blev udgivet, kendtes dette originale, gule omslag kun fra en beskrivelse i Carl Kochs bog »Grundtvigske Toner« fra 1925 (s. 38). Et andet eksemplar, ligeledes med det originale omslag bevaret, tilhører prof. Hal Koch.

Det vil her være på sin plads at sige lidt mere om de originale omslag på Gr.s publikationer fra I820'erne. Steen Johansen har ganske kort, $i$ et afsnit trykt med petit, strejfet dette emne $i$ indledningen til tredie bind af Bibl. Emnet har imidlertid været af en så speciel karakter, at Bibl.s forfatter ikke har kunnet uddybe det nærmere, men han giver dog, som nævnt, et par antydninger. Disse antydninger er vi nu, på grundlag af materialet i den Thorsenske samling, i stand til at supplere og korrigere. Det er karakteristisk for Gr.s udgivelser i tiden til og med I820, at de udkommer med stumt omslag, d. v.s. uden påtryk af nogen art. Kun enkelte undtagelser kendes. Imidlertid sker der i løbet af i 820'erne en overgang til påtrykte omslag, da, for at citere Bibl. : »Nyaars-Morgen 1824 og Kong Harald og Ansgar I826 begge udkom med omslag med forfatternavn og titel, medens Kirkens Gienmæle 1825 udkom med stumt omslag $\left.\ll^{2 \mathrm{a}}\right)$. De herværende eksemplarer af »Nyaars-Morgen « og af »Kong Harald og Ansgar« bærer imidlertid på de originale omslag kun titel og ikke forfatternavn. Derimod har udgaven af »Krønike-Riim《, I829, både titel og forfatternavn, hvilket iøvrigt også gælder flere af skrifterne fra I83o'erne.

Gr.s lille skrift »Kong Harald og Ansgar« udkom første gang i I826 og i anden udgave i r 865. Begge udgaverne haves plus et korrektureksemplar, der angiver hvilke rettelser, der er foretaget i 2. udgaven. $\mathrm{På}$ indersiden af førsteudgavens medindbundne, oprindelige bløde omslag læses: »Mig foræret af min Fader 1826 ved Jubelfesten. C. Ley.« Bogen har derfor tilhørt Christian Sigfred Ley, der var en

1) Omtalt af Toldberg i Gr. Stud. I 948 s. $53 \mathrm{f}$.

2) Her og i det flg. forkortelse for Steen Johansen: Bibliografi over N.F.S. Grundtvigs Skrifter I-IV, 1948-1954.

${ }^{2 a}$ ) Bibl. III, 3. - Bibl. I, I 82 og 206 anfører rigtigt, at kun titelerne var trykt på omslaget. 
af Gr.s trofaste tilhængere, og hvis optegnelser iøvrigt er en vigtig kilde til vor viden om Gr.s $\operatorname{liv}^{3}$ ). Blyantnotitsen på indersiden af det senere bind »Med Grundtvigs Korrekturrettelser« er imidlertid næppe rigtig. For det første fordi skriften i rettelserne ikke ligner Gr.s og da slet ikke hans skrift fra I86o'erne! For det andet: hvorfor skulde Gr. indskrive sine rettelser i et eksemplar, der ikke tilhørte ham selv? Sagen er snarere den, at bogens ejer, Ley, i I 865 har sammenlignet de to udgaver og da i den tidligste udgave har noteret ændringerne $\mathrm{i}$ andenudgaven.

Det næste skrift, der påkalder vor opmærksomhed, er et lille samlehefte: Chr. Thaarups »Dansk Bibliothek, Et Hæfteskrift« fra I 827, hvori der findes et tryk af Gr.s digt om Jørgen Sorterup. Dette digt tryktes første gang i digtsamlingen »Idunna « fra I8 I o-I I og har i første udgave og $\mathrm{i}$ anden udgave fra 18 i 58 vers. I dette tryk, der forøvrigt ikke nævnes i Bibl., er kun 6 vers. - Gr.s »Krønike-Riim《 fra I 829 er allerede omtalt. Det skal derfor her blot nævnes, at det haves i to eksemplarer, eet med det originale, grå, bogtrykte omslag, og eet i bogtrykt, gul kartonnage. Dette sidstnævnte eksemplar er iøvrigt eet af de ovf. nævnte ubeskårne eksemplarer. - Af det lille skrift »Historisk Børne-Lærdom《, udkom hele 9 oplag i tiden I829-90. At femte oplag udkom med to forskellige trykår - både med r845 og med r 846 - på titelbladet, har man imidlertid ikke vidst før nu. Trykket med I845 er muligvis et fejltryk og synes iøvrigt at være identisk med r 846-trykket. At Thorsen også har fundet frem til dette ejendommelige, lille tryk, er et smukt vidnesbyrd om hans fine sporsans. - At der i samlingen findes et eksemplar af Søndagsbogen I-III, der har tilhørt Skat Rørdam, og at J. Chr. Lindbergs »Maanedsskrift for Christendom og Historie « haves med de originale hefteomslag skal lige nævnes, før vi går over til en omtale af skrifterne fra trediverne. Disse byder nu ikke på store overraskelser. Af den tyske udgave af Gr.s »Politiske Betragtninger...« fra I83 I haves eksemplarer både med blåt og med gult omslag. Af førsteudgaven af Gr.s Sangværk haves biskop Martensens eksemplar, og Gr.s »Nordiske Smaadigte《 fra $183^{8}$ prydes af en egenhændig dedikation: »Til Venne-Skjalden B. S. Ingemann i Soer fra N. F. S. Grundtvig paa Amager.« Dernæst bemærkes »Det Danske Fiir-Kløver《 fra $18{ }_{3} 6$ med det originale, bogtrykte omslag, både $\mathrm{i}$ rødbrunt og $\mathrm{i}$ gult.

3) Jf. Grundtvigs Erindringer og Erindringer om Grundtvig, i Udvalg ved Steen Johansen og Henning Høirup, I948, s. 289. 
Blandt skrifterne fra I840'erne bemærkes først 》Mundsmag af Danmarks Krønike til Levende Skolebrug«, der udkom i ialt 5 oplag i tiden 1842-77. I Bibl. bemærkes det, at der iflg. kataloget over Svend Gr.s bogsamling skulde have eksisteret et eksemplar af bogens tredie oplag ( 1863 ) trykt på tykt papir. Et sådant eksemplar findes i Instituttets Gr. samling, men om det har været Svend Gr.s får stå hen. - Fra I844 haves endnu et dedikationseksemplar. Det drejer sig om »Skov-Hornets Klang mellem Skamlings-Bankerne«, hvori Gr. har skrevet »Til min systerlige Veninde Jane Blicher fra Forf.« Dedikationen har oprindelig været skrevet på det blå papiromslag, men det er nu indklæbet forrest i bogen. Jane Blicher var søster til Gr.s første kone, Lise Blicher.

Vi bliver nu nødt til - ganske kort - at strejfe det store forskningsområde, der hedder Gr.s salmer. Her skal blot fremdrages et enkelt eksempel, nemlig tredie oplag af Fest-Psalmer fra i85 I. Af denne udgivelse haves to eksemplarer, et med 699 numre, 84 sider plus register, og et med 700 numre, 85 sider plus register. Tredie oplags nr. 700 er altergangssalmen $\gg \mathrm{O}$ Jesus! paa din Alterfod ...« en oprindelig Kingo-salme, som Gr. havde bearbejdet allerede i I 8 Io og senere nybearbejdet og trykt i de »Trykte Salmeblade« fra 1844 og i Prøveheftet fra $1845^{4}$ ). I Fest-Psalmer optræder salmen iflg. Bibl. ${ }^{5}$ ) for første gang i fjerde oplag af Fest Psalmer fra i 852. Steen Johansen kender imidlertid også et tryk af salmen overskrevet med nr. 700 på et blad pagineret 85 , og han stiller da det spørgsmål ${ }^{6}$ ), hvor dette tryk stammer fra. Svaret kan nu gives: Trykket stammer fra tredie oplag af Fest-Psalmer, der blev udsendt i r 85 I, og hvoraf altså nogle eksemplarer havde 700 numre og 85 sider plus register. Det anførte eksempel viser, at det vil kunne lønne sig for en salmeforsker at gennemarbejde Instituttets samling af de forskellige oplag af Fest-Psalmer, og her skal blot tilføjes, at af syvende oplag ( 1856) haves 5 forskellige eksemplarer. Endv. vil de talrige salmeblade, der findes i småtryksamlingens ottende kuvert have interesse for enhver, der vil studere Gr.s salmer.

I anledning af vennemødet i september $186_{3}$ blev der udgivet et lille skrift af Gr. : »Den levende Røst«. I løbet af et par måneder udsendtes et andet oplag med enkelte småændringer, og hele skriftet

$\left.{ }^{4}\right)$ Bibl. nr. 796 c. 14 og 804 A. 22.

5) Bibl. nr. 796 c. I4 og Iо 8 .

$\left.{ }^{6}\right)$ Bibl. nr. Iо 8 . 
blev siden optrykt $\mathrm{i}$ femte bind af »Salmer og aandelige Sange fra I88 I. I udgiverens noter bag i dette bind (s. 862) omtales, at »I et Expl. af »Den levende Røst«, andet Oplag, har Forf. indskrevet følgende Ændringer . . «, hvilke ændringer derpå anføres. Dette eksemplar med Gr.s egenhændige ændringer (med henblik på en tredie udgave?) findes i Instituttets eje. På bogens forsats er skrevet med Skat Rørdams håndskrift, at bogen »blev købt paa Grundtvigs Auktion«, hvorpå følger bl. a. en henvisning til auktionskatalogets s. 296 nr. 878 .

Før vi forlader denne afdeling af samlingen, skal det nævnes, at Gr. i et eksemplar af »Den christelige Børnelærdom《, 2. udg. I868, har indskrevet dedikationen: »Til Nany Bech venligst N.F.S. Grundtvig. I 87 I.《 Navnet på modtageren er overordentlig vanskeligt at læse. I kataloget karakteriseres det ligefrem som »ikke læseligt«, men ved Steen Johansens hjælp er det nu lykkedes at tyde skriften og at identificere personen bag navnet. Nanny Johanne Mathilde Henriette Bech ( $1819-1898$ ) var svigerinde til den kendte grundtvigske præst, Gunni Busck, og søster til den H. Bech, der udgav en bog om Busck ${ }^{7}$ ).

Vi kommer nu til Småtryksamlingen, der er samlet i en stor arkivæske og anbragt under den egentlige Gr.samling. Sammenligner man indholdet af denne samling med det meget store antal af småtryk, der er anført i Bibl., bliver det klart, at denne afdeling af Instituttets Gr. samling langt fra er komplet. Men derfor rummer den dog alligevel nogle tryk, der ikke omtales i Bibl. Det gælder således et tryk af »Langt højere Bjerge«, hvor det af småtrykkets titelblad fremgår, at sangen har været »Afsjunget paa Concerten paa Odense Raadhuussal, d. 30. Jan. I 837.« Dette tryk anfører kun fire vers af det kendte digt. - Nævnes må også et iøvrigt ukendt tryk af »Moders Navn ...« og af digtet »Om Dannemarks Qvide, der lød en Sang . « De findes i et lille sanghefte med udskriften: »Concert i Gladsaxe Kirke, Søndagen den 22de September 1850. Til Fordel for de Saarede og Faldnes Efterladte.« - Endv. må nævnes et tilsyneladende ukendt tryk af visen om general Wrangel (Bibl. nr. 926). Selve visen er fra 1848 , men den haves her $i$ et optryk i 6.te samling af en serie sangblade $\gg$ Nye danske Krigssange«, Haderslev I850. - Endelig må nævnes et mindre antal

7) Henr. Bech: Gunni Busck, et Levnetsløb i en Landsby-Præstegaard, r 869. Om Nanny Bech, se Minder fra gamle grundtvigske Hjem III, I923, s. I oo $\mathrm{f}$ og r $80 \mathrm{f}$ jf. I i $34 \mathrm{f}$. Jeg takker Steen Johansen for disse oplysninger. 
særtryk af kendte Gr.digte udgivet af »Udvalget for Folkeoplysningens Fremme,« I 867-68. Også disse tryk er tilsyneladende ukendte. Det samme gælder tre velkendte Gr. digte, der er trykt i et lille sanghefte med udskriften »Sange ved Indvielsen af Friskolen i Høiby den Igde Juli i869. Trykt hos Carl Tiedje i Odense.« Foruden denne samling af Gr.tryk indeholder småtryksamlingen også en del tryk af sange om og til Gr. Det gælder således Barfods og Kaalunds sange ved den sidste Mands Mindeforelæsning i efteråret i 838, det gælder Ingemanns digt i anledning af Gr.s sølvbryllup i I 843, det gælder endv. J. Th. Rørdams hyldestdigt til Gr. under Norgesfærden i I85 I og sangene, der blev sunget ved præstejubilæet I86I, og endelig gælder det også Bjørnsons berømte digt ved vennemødet $\mathbf{i}$ Kasino efter Gr.s død i I872. - Endelig rummer denne afdeling af samlingen nogle småtryk, hvis forbindelse med Gr. ikke er umiddelbart indlysende. Dem er der derfor ingen grund til at komme nærmere ind på her.

Vi vil bevæge os fra samlingens centrale dele, nemlig samlingen af Gr.tryk, over i de mere perifere områder. Men også disse områder rummer interessante tryk, og de yder dermed atter et bevis for N. F. Thorsens fantastiske evner som samler. Først vil vi se lidt på en samling, der er katalogiseret under betegnelsen »Gr.s slægt og familie«. Denne samling rummer skrifter af Johan Gr., Gr.s fader, af Otto Gr., Gr.s broder, og af Gr.s sønner Svend og F. L. Gr. Hertil slutter sig nogle mindeskrifter om enkelte familiemedlemmer, eller om slægten som sådan. - Den største kostbarhed i denne afdeling af samlingen er et fuldstændigt eksemplar af det ugeskrift »Brevduen«, som F. L. Gr. udgav som dreng sammen med Svend Høgsbro og brødrene Joakim og Niels Skovgaard. Fuldstændigt er dette eksemplar dog kun, for så vidt som det omfatter alle de udkomne numre, men det mangler det titelblad på hele årgangen, som kendes fra de eksemplarer af ugeskriftet, der beror på Skovgaard-musæet i Viborg og på Kgl. Bibliotek. Men det synes iøvrigt at være det ene af de tre eksisterende komplette samlinger af dette morsomme, lille ugeskrift $\left.{ }^{8}\right)$. Dette eksemplar af »Brevduen« har tilhørt Gr.s kusk og er blevet skænket til Instituttet af prof. Hal Koch.

En del af eksemplarerne af F. L. Gr.s bøger er forsynet med hans navnetræk, og nogle har tilhørt andre medlemmer af den nær-

${ }^{8}$ ) Jf. H. E. Eriksens bibliografi i H. Høirup m. fl.: Frederik Lange Grundtvig, I955, s. I $73 \mathrm{f}$. 
meste familie og er i den anledning forsynet med tilegnelsesdigte af F. L. Gr. Således har han indskrevet et tilegnelsesdigt »Til min store Søsterdatter Elisabeth Boisen« $i$ et eksemplar af pjecen »Kongebørnene« fra I87I. Nok så interessante er dog tilegnelsesdigtene til den ældre broder Svend Gr. I et eksemplar af første oplag af F. L. Gr.s »Rimbrev til Gr.s Venner« ( I875) kan læses et digt til broderen sluttende med linierne:

»Hav Tak, fordi til Skridtet du mig raaded,

Om andre ej, - mig selv det dog har baadet.«

I et eksemplar af Rimbrevets femte oplag er atter indskrevet et tilegnelsesdigt »Til min kjære Broder Svend som stod Fadder til Rimbrevet«. Digtet slutter ganske pudsigt med en hentydning til Bjørnson :
».....i næste Folketidende
Skal du se en extra bidende
Artikel af »en Nordmand «, som bilder sig ind, at af Thor han
Har laant den vældige Hammer, -
Saa gjælder det at slippe uden Skrammer«.

Ingen af disse digte var kendt i i 955, da Høirups bog om F. L. Gr. udkom. - Til slut skal nævnes, at Instituttet har et korrektureksemplar af første udgave af F. L. Gr.s Rimbrev med forfatterens egenhændige rettelser og tilføjelser. Atter må man beklage, at den Thorsenske samling har ligget gemt hen i så lang tid! Samlingen af og om F. L. Gr. indeholder også en bog, som han har ejet, samt de fire første udgaver af hans »Sangbog for det danske Folk i Amerika«.

Går vi videre i samlingen, finder vi en del bøger, der dels er af Svend Gr., dels har tilhørt ham. Disse sidste kan være forsynet med dedikationer til Svend Gr., eller også med notater og indstregninger af ham. Af de fire bøger af Svend Gr., som samlingen indeholder, bærer tre hans egenhændige dedikation.

Vi kommer nu til en afdeling af samlingen, der er katalogiseret under betegnelsen »Grundtvigs Bogsamling«. Indf. den nyere $\mathrm{Gr}$. forskning har man i stedse voksende grad interesseret sig for at studere - evt. rekonstruerere - Gr.s bogsamling. Denne interesse udspringer af det synspunkt, som Helge Toldberg har formuleret i sin bog »Grundtvig som Filolog«: »De bøger, Gr. har ejet eller laant, har haft en langt større indflydelse paa hans forfatterskab end almindeligt antaget.«(s. 40). I den nævnte bog gør Dr. Toldberg da Gr.s 
bogsamling - og Gr.s læsning - til genstand for undersøgelse i et helt kapitel. Instituttet ejer en samling på I4 bøger, som har været Gr.s, og nogle af dem er forsynet med notater og tilføjelser i Gr.s håndskrift. Lad os se nærmere på et par af de vigtigste.

Den første i rækken er Gr.s eksemplar af faderens, Johan Gr.s bog »Catechismi Forklaring efter Saliggiørelsens Orden《 ( I 779). På titelbladet er skrevet med blæk: »d. I 2. jan. I79r. N. F. S. Grundtvig.« Skriften er ikke Gr.s snarere faderens. Nedenunder er tilføjet ligeledes med blæk - »d. I6.de Octbr. I873. G. P. Brammer.« Brammer var den senere biskop, der i sin ungdom var stærkt påvirket af Gr., men som da med årene fjernede sig mere og mere fra ham og blev modstander af Grundtvigianismen ${ }^{9}$ ). At Brammer på auktionen over Gr.s bogsamling har købt denne bog, der havde tilhørt Gr., kan dog tages som et vidnesbyrd om den kærlighed han trods alt nærede for sin ungdoms læremester ${ }^{10}$ ). Rundt omkring i bogen er der med Gr.s håndskrift - og med blæk - gjort forskellige tilføjelser. Ganske pudsige er hans forsøg på at oversætte visse ord og vendinger til latin. Således er vendingen »Til den høystærede Læser《 oversat »Lectori benevolo.« Denne oversættelse er fuldtud forsvarlig, men oversættelsen af »Gud allene Ære« med »deo solo gloria« er forkert. Disse oversættelser må antages at være blandt de ældste kendte, skriftlige nedslag af $\mathrm{Gr} . \mathrm{s}$ bekendtskab med det latinske sprog, der iflg. Toldberg tilhører det sidste år i Thyregod ( I 798) og Aarhustiden ${ }^{11}$ ). Denne antagelse støttes af den kendsgerning, at et forsatsblad, der er

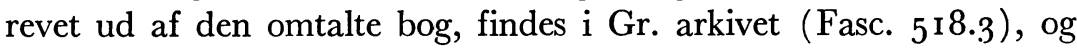
at Gr. på dette blad har nedskrevet nogle betragtninger på latin og nedenunder har tilføjet datoen 9/4 I798. Der er al god grund til at formode, at de anførte oversættelser er nogenlunde samtidige med betragtningerne på det løse blad, hvis eksistens og plads i arkivet Steen Johansen venligst har gjort mig opmærksom på. Betragtningerne har forøvrigt været omtalt hos Rønning i dennes bog »Den grundtvigske Slægt $\left.\ll^{12}\right)$. Til Gr.arkivet er de kommet i marts 1877 , da Brammer sendte C. J. Brandt bladet. Det fremgår af et brev fra Brammer til Brandt indlagt sammen med betragtningerne $i$ fasc. $5^{18.3}$.

$\left.{ }^{9}\right)$ Jf. F. Elle Jensen: Biskop Brammer og Grundtvigianerne, Aarhus Stifts Aarbøger, 1955, s. 90 ff.

10) Sml. Biskop, Dr. theol. G. P. Brammers Ungdomsliv, udg. af J. Kok, I884, s. 107 noten.

11) H. Toldberg: Grundtvig som Filolog, 1946, s. 94 .

12) r 904 . s. 88. 
Foruden disse tilføjelser med Gr.s hånd findes på side I 78 en kaligraferet fortsættelse af bogens $\S 537$. Hvem, der er ophavsmand til denne tilføjelse, er ikke let at afgøre. Muligvis er det Johan Gr. Endv. findes der hist og her i bogen nogle blyantunderstregninger og notater med fremmed hånd, muligvis Brammers.

Den næste bog i rækken er Chr. G. Heynes udgave »Apollodori Atheniensis Bibliothecæ Libri Tres, « Göttingen I 782. På indersiden af omslaget har F. L. Gr. indskrevet sit navn og har tilføjet »N. F. S. Grundtvigs Exemplar«. - Dernæst kommer en række skrifter med dedikationer fra forf. til Gr. Her bemærker man P. C. Kierkegaards disputats fra $183_{3} 6$ med dedikationen: $\gg$ Til Herr Pastor N.F.S. Grundtvig med Taknemmelighed og Venskab fra Forf.« Endv. bemærkes Fr. Hammerichs »Om Studiet af Kirkehistorien« ( I 859), der er forsynet med indstregninger og notater, der kan være af Gr.- Længere henne i rækken ses Gr.s norske Ny Testamente, der blev skænket ham af Wilh. Wexels. Efter Gr.s død overgik bogen til husets faktotum, frk. Filipine Larsen. Ved hendes død i ig I I blev bogen testamenteret til Holger Begtrup.

Sidst i rækken står to bøger i kvart-format. Den første er »Sagan af Gunnlaugi Ormstungu ok Skalld Rafni« ( I775). På forsatsen har Gr. skrevet, hvad han i sin tid har betalt for bogen i rå materie samt, hvad han har givet for indbindingen. Det næste værk er en sand lækkerbidsken for filologer. Det er Ulfilas gotiske bibeloversættelse i Iohan Chr. Zahns udgave fra I805. Bogen har tilhørt Gr. og derefter Svend Gr. Glossariet i bogens sidste del har Gr. forsynet med talrige notater - både med blæk og med blyant. Disse notater giver os et interessant indblik i Gr.s syn på forskellige ords etymologi. At det virkelig er Gr., og ikke Svend Gr., der er ophavsmand til disse tilføjelser, fremgår deraf, at Svend Gr. under sit navnetræk foran i bogen har skrevet »Tilføjelser med N. F. S. Grundtvigs hånd «.

Som tidl. omtalt ejer Instituttet en samling af Gr. udklip, der opbevares i fire store papkasetter. Samlingen stammer dels - som nævnt - fra grosserer H. I. Andersens samling (via Rosenkilde og Bagger), dels fra en ikke ubetydelig udklipsamling, som Instituttet har erhvervet fra fhv. byretsbetjent P. Beeskes bo. Den første af kasetterne indeholder udklip med Gr. tekster, og de to næste rummer udklip, der omhandler Gr., og den sidste indeholder klip, der omhandler Gr.s slægt, Grundtvigianismen, Højskolen, Vartov, Grundtvigs-Kirken o.s. v. I samlingen af klip med Gr.tekster er kun noteret tre, der ikke var 
registreret i Bibl. Det drejer sig om tryk af digtene. »Det var Kong Rolf, han slog med Sværd«, »Herop! herud nu ret paa Stand « og endelig »Med Almagt troner Erens Drot«. Alle disse udklip hidrører fra »Folkebladet Fylla《 fra årene I872-73 (20/4-27/4 - og 19/4).

Klippene om Gr. strækker sig over tidsrummet i848-1957. Enkelte er dog udaterede, andre igen er anonyme. Dog vil man ret hurtigt kunne finde frem til, hvad man interesserer sig for, igennem kartoteket. I kuverten med »anonyme klip« noteres en indtegningsliste med navne på folk, der vilde bidrage økonomisk til den »Skuemønt«, der blev slået i anledning af Gr.s præstejubilæum i I86r. - Hvilken værdi har nu en sådan udklipsamling? Er det umagen værd at fortsætte den? Det viste sig jo, at den ikke rummede ret mange overraskelser. Og dog. En sådan samling må trods alt siges at have en vis interesse, nemlig for den, der vil studerere Gr.interessens og Gr.opfattelsens historie. Og så rummer samlingen da endelig også overraskelser, selv om det ikke er mange. - Skal man fortsætte denne samling? Både ja og nej. Man vil ikke fortsætte med at samle udkljp, der er kommet i tiden efter 1945, idet vi jo nu hvert år i Grundtvig-Studier får Steen Johansens fortræffelige oversigt over den Gr.litteratur, der udkommer. Men så vidt det kan lade sig gøre, vil man fortsætte med at samle klip fra tiden mellem Gr.s død i 1872 og 1945. Tidsskriftartikler fra dette tidsrum er i det store hele ukendt område for Gr.forskningen, der, hvad tidsskriftartikler angår, væsentligst interesserer sig for det, der er skrevet om Gr. i tiden før hans død og så for det, der er skrevet i den allernyeste tid, i tiden efter 1945. Området er naturligvis bearbejdet af de forskere, der studerer Grundtvigianismens histori $^{13}$ ), men for Gr.forskningens vedkommende må den herværende udklipsamling siges at udfylde et savn, og man har kun grund til at takke de flittige samlere, der har skabt denne samling.

Som tidl. nævnt ejer Instituttet en samling af noder til Gr.s salmer og digte og en samling af Gr.billeder. Udforskningen af nodesamlingen, der forøvrigt ikke er særlig stor, vil være en passende opgave for den musikhistorisk kyndige Gr.forsker. - Billedsamlingen rummer ca. 85 billeder, hvoraf nogle er dubletter, og I0-I5 stk. ikke er billeder af Gr., men af medlemmer af Gr.s slægt og familie, og af »minderige steder i Gr.s liv«. En foreløbig gennemgang af denne billedsamling frembyder ingen overraskelser. Hvad Gr.billeder

${ }^{13}$ ) Jf. f. eks. A. Pontoppidan Thyssen: Den nygrundtvigske Bevægelse, I, I958. 
angår, er den egentlige overraskelse kommet fra udklipsamlingen. Denne »opdagelse« håber jeg senere at kunne komme tilbage til i en selvstændig undersøgelse.

Endelig skal omtales den afdeling af samlingen, der alene ved sin katalogbetegnelse »Inedita « må vække forskernes nysgerrighed. Samlingen er dog ikke særlig stor. Den omfatter kun 7 hefter og bind, hvoraf de 4 er afskrifter af allerede kendte og trykte digte f. eks. »Dansk Ravne-Galder $\ll^{14}$ ). Et af hefterne indeholder en trykt følgeskrivelse til nogle tryksager vedr. »Den Danske Forening « og er dateret den 23/4 I853 $3^{15}$ ). Følgeskrivelsen bærer Gr.s autograf, hvilket er det eneste, der kvalificerer skrivelsen til at høre med til denne afdeling af samlingen - Et andet hefte indeholder et utrykt brev omhandlende Gr.s sindssygdom i i 867 . Det lyder som følger:

Kjøbenhavn d. 28. April 1867 .

»Igaaer kjære Forældre bragte Louise Eder en Hilsen fra mig indeholdende: at jeg havde $\langle$ det $\rangle$ godt o. s. v. imidlertid afholder dette mig dog ikke fra at tilskrive $\langle$ Eder $\rangle$ Lidt idag.

Først maa jeg meddele Dig, kjære Fader, at det som Følge af de utroligste Røverhistorier om Grundtvig, er en aldeles Umulighed at skaffe noget paalideligt Referat af hans Optræden Palmesøndag, dog troer jeg Det, Du veed, er sandt, og endvidere efter Tjenesten skal han have kysset Dronningen sigende: Lad dette befrugte Dig til at føde en Holger Danske med Tilføiende om Preussernes Komme. I det hele taget skal han nu leve $\mathbf{i}$ den Illusion, at man overhovedet ikke behøver at leve som Mand og Kone for at formere sig; men naar man kun har Troen paa et Kys's Virkning skulde dette kunne frembringe Arvinger. ( $\mathrm{I}$ juridisk Henseende troer jeg næppe en saadan Fødsel blev taget gyldig med Hensyn til Arveberettigelse). Han skal paa Frederiksdahl, hvor de er flyttet ud, $\langle\mathrm{og}\rangle$ tale meget om at omskiære Hjerterne og Ørerne paa Folk.

Same Dag var der Daab i Vartou og ved denne Leilighed skal han have sagt, idet Barnet begyndte at græde: »Bryd Dig ikke om det; thi det er Djævelen der farer ud af Dig «. De omtalte Blade har jeg bedet min Boghandler skaffe, ...«(Resten af brevet er af privat natur).

underskrevet: »Chr. Møhl $\left.\ll^{16}\right)$.

14) Et femte hefte indeholder et håndskrevet digt, der sandsynligvis ikke er af Gr. -

15) NB. Bibl. nr. I040 især note I, S. I15.

16) Julius Christian Møhl, stud. jur., søn af ovf. omtalte pastor K. E. Møhl. 
De i brevet nævnte begivenheder kendes fra andre kilder. I detailspørgsmål bør man ikke tillægge brevet nogen værdi, da det jo bygger udelukkende på anden- og trediehåndsviden.

Vi er nu nået til vejs ende med gennemgangen af Instituttets Gr. samling. Omtalen af de mange bogtitler, årstal, oplag, udgaver, omslag, dedikationer, trykt og utrykt, alt dette gør et broget og flimrende indtryk, når man nu ser tilbage. Men forhåbentlig har dog det hovedindtryk fæstnet sig: at denne Gr.samling virkelig er en stor og værdifuld samling, der nok er værd at stifte bekendtskab med - alene af den grund, at der her vitterlig findes ikke så få Grundtvigiana, der ikke findes andre steder. Instituttets Gr.samling er sandsynligvis en af landets tre bedste. Her tænkes på Det Kgl. Biblioteks og Grundtvig-Bibliotekets samlinger, der er de eneste, der kan sammenlignes med Instituttets. Disse tre store samlinger supplerer hinanden udmærket; hver af dem har Grundtvigiana, som de to andre ikke har $^{17}$ ).

Lad da disse linier være en invitation til alle Gr. forskere og Gr.interesserede til at aflægge Instituttet et besøg. Der er utvivlsomt endnu et og andet $\mathrm{i}$ samlingen, der venter på at blive opdaget!

17) Også Gr. samlingen på Askov Højskoles bibliotek rummer store sjældenheder, jf. omtalen hos Toldberg: Gr. som Filolog, s. 29. 